\title{
What Would John Dewey Say About the Educational Metamorphoses of Malcolm X?
}

\author{
Magnus O. Bassey
}

\begin{abstract}
Malcolm X in his autobiography claimed that every experience he had as a youth was educative. Such a claim confronts us, as educators, with a serious dilemma, that is, whether all transformations and human experiences are educative. In reviewing John Dewey's major writings on the topic, the author concludes that some of Malcolm X's early experiences were not educative although his re-education through the instrumentality of the Nation of Islam served him well as an educative experience because it liberated him from the destructive rendition of the social order.
\end{abstract}

\section{Introduction}

In two of his major works, Experience and Education and Democracy and Education, John Dewey argued that there is an organic connection between experience and education. Dewey went on to state that a student's experience is the result of the interplay between the student and his or her environment. (Carver \& Enfield, 2006). In other words, students are affected in their learning by internal factors and by their environments guided by the principles of interaction and continuity. This means that predispositions that students developed from past experiences affect their future experiences (Carver \& Enfield, 2006). However, Dewey also stated that while some experiences are educative, other experiences may be mis-educative. In this article, I argue that a strong evidence for Dewey's assertion concerning educative and mis-educative experience can be found in Malcolm X's life story. Indeed, in reviewing the major writings of John Dewey (specifically, Experience and Education and Democracy and Education) and reading the autobiography of Malcolm X and the other works about him, I have come to the conclusion that some of Malcolm 
$\mathrm{X}$ 's early experiences were not educative, but his re-education through the instrumentality of the Nation of Islam served as an educative experience because it started him on the process of self-discovery, self-analysis, resistance, and critique.

In his autobiography, Malcolm X states: "I finished the eighth grade in Mason, Michigan. My high school was the black ghetto of Roxbury, Massachusetts. My college was in the streets of Harlem, and my master's was taken in prison" (1992a, p. 282). This means that Malcolm $X$ underwent four fundamental educational metamorphoses or transformations. The questions posed by the above statements are:

1. What is the relationship between experience and education?

2. Are all experiences educative?

3. What is the difference between educative and mis-educative experience?

4. Is education simply a question of transformation or is it transformation towards something? To answer these questions, it is important to examine the educational journey of Malcolm X through the lens of what the most renowned American philosopher of education, John Dewey, describes as education and educative experience.

\section{Who Was Malcolm X?}

Malcolm X's life story has been told several times and is fairly well known (see Malcolm X, 1992a; Spike Lee's film, Malcolm X, 1992; The Western Journal of Black Studies, 1993). This said, it is important to point out that Malcolm X started his nightmarish early life as Malcolm Little on May 19, 1925. In his early adolescence he descended into the darker side of American society as he pilfered from people and people preyed on him. His criminality led to his callous indifference towards human suffering resulting in his perception of human beings, especially women, as commodities to be exploited. As a result of his early criminal activities and the hustle and bustle of city life in Boston and New York City, Malcolm ended up as a convict in Charlestown State Prison at about the age of twenty. However, due to a series of corrective influences in Charlestown State Prison and at Norfolk Prison Colony, Malcolm converted to an "inclusive humanism" leading to his rebirth and transformation as a charismatic and influential Muslim Minister before his untimely death on February 21, 1965.

Roda (2005) argues that Malcolm's "life was cut short at a time when he appeared to be on the threshold of conversion to an inclusive humanism. . . . His tortuous odyssey provides one with a vivid narrative of the nightmarish African American experience." He concludes that Malcolm's ordeal was the "story of a human being caught in a web of absurd and perverse social forces in a struggle for his own humanity and self-esteem" (p. i). Perhaps, Roda is right because in Experience and Education, Dewey (1938/1998) saw an organic connection between experience and education. 


\section{What is Education and What is an Educative Experience?}

Dewey offered a general perspective that provides some frame of reference about the definition of education and educative experience in two of his illustrious works. In Experience and Education, and Democracy and Education, Dewey defines education as growth and educative experience as continuity through renewal. He argues that, "every experience both takes up something from those which have gone before and modifies in some way the quality of those which come after (1938/1998, p. 27). He postulates that a student's experience derives from the interaction between the student and his or her environment. Therefore, education is the means of social continuity of life. But as he puts it, some experiences are mis-educative. An experience is mis-educative if it "has the effect of arresting or distorting the growth of further experience" (p. 13).

Martusewicz argues that "transformations [which] reproduce conditions, e.g., ideologies, attitudes, relationships or practices, or social and economic structures that may be harmful to others" are to be considered mis-educative (2004, p. 4). In a similar vein, Dewey argues that "growth, or growing as developing, not only physically but intellectually and morally, is one exemplification of the principle of continuity" (1938/1998, p. 28). However, a man who grows in efficiency as a burglar, or as a gangster or as a corrupt politician cannot qualify from the "standpoint of growth as education and education as growth" (p. 29). Dewey likens educative experience to a moving force whose true value can be judged based only on what it moves toward and what it moves into (p. 31). Indeed, he maintains that growth in and of itself is not enough and stresses the importance of taking into account the direction in which growth takes as well as its final result (p. 28).

\section{What is the Difference between Educative and Mis-educative Experience?}

As I have already pointed out, Dewey saw educative experience as growth that allows for further growth. He points out that experiences that are harmful to others are mis-educative. If Dewey's position is accepted, it is clear that Malcolm X did not undergo useful educative experiences during his years on the streets of Boston and New York City as he claims, because in his early adult life, Malcolm was a hustler, a pimp, a thief, and a parasite who distrusted people, especially women, and preyed on them. Indeed, Malcolm admits sliding down the path of mis-education in his early adolescence when he states, "I believe that it would be almost impossible to find anywhere in America a black man who has lived further down in the mud of human society than I have" (1992a, p. 379). By his own admission, Malcolm exhibited callous and inexorable behaviors - mis-educative behaviors by Dewey's definition. Notice also that while Malcolm X lived by the dictum that certain objectives should be achieved by "any means necessary," Dewey offered a definition of educational experience that presupposes a systematic scientific endeavor with an organic connection between experience and education. 
Similarly, Carter G. Woodson (1875-1950), a contemporary of John Dewey, offered another definition of mis-education. In his ground-breaking book, The MisEducation of the Negro (1933/1993), he noted that blacks were given the wrong type of education because their education was not drawn from their own experiences. He lamented that the type of education blacks received in America was mis-educative because it "created a split in the personality of [African Americans] typified by dual identities resulting in a profound identity crises which has made educated [African Americans]," to "decry any such thing as race consciousness" (p. 7). He states,

THE "educated Negroes" have the attitude of contempt toward their own people because in their own as well as in their mixed schools Negroes are taught to admire the Hebrew, the Greek, the Latin and the Teuton and to despise the African. (p. 1)

Woodson goes on to note that "the Chief difficulty with the education of the Negro is that it has been largely imitation resulting in the enslavement of his mind" (p. 134). As a corrective to the mis-education of blacks, Woodson suggests that African Americans should be given the type of education that is not imposed from without, that is, the type of education that is determined by the make-up of the people themselves and by what their environment requires of them. This type of education, according to Woodson, enables individuals to think for themselves. The implication here is that even the little formal education Malcolm X received in his early years would qualify as mis-education, according to Woodson's definition, because such an education was not grounded in Malcolm's own experiences and "what his environment requires of him" (p. x).

\section{The Re-education of Malcolm X}

Perhaps it is instructive to say that the most crucial way of approaching an education project is by going beyond the enculturation of the young to producing knowledgeable and engaged citizens who would be able to confront democratic incongruities, contradictions and imperfections. Part of this challenge, according to Giroux (2006), is for education and pedagogy to be "central to the political tasks of reclaiming public space, rekindling the importance of public connectedness, and infusing civic life with the importance of a democratic worldly vision ...." (p. 73). Giroux goes on to argue that democracy must be "nurtured in those public spaces (like schools) in which 'the unconditional freedom to question' becomes central to any viable definition of individual and social agency" (p. 71). Indeed, at the time Dewey wrote some of his works, the American public, educators and education philosophers "wanted schools to assimilate students into American life, combining the basics of English and arithmetic with emphasis on patriotism, hard work, fair play, and honesty" (Graham, 2005). According to Graham, "John Dewey and his high-toned colleagues had much more subtle notions of patriotism in mind, ones that recognized the obligations of both the citizen to the state and of the state to the citizen, including the citizens' responsibility to serve the state 
through their enlightened criticism of it" (2005, p. 24). Matthew C. Altman concurs that citizenship education should "prepare students to participate in public dialogue about questions of justice and morality" (qtd. in Waghid 2005, p. 323). It is here that Malcolm's re-education through the instrumentality of the Nation of Islam and self-study served him most adequately because it liberated him from "the destructive definitions constructed by the social order" (Roda, 2005, p. ii), and prepared him to question society's excesses.

At the time Malcolm X lived, African Americans suffered material exploitation and deprivation, the most serious being the exploitation of self-esteem. The fate of African Americans was best described in Ralph Ellison's (1947/1994) bestselling book, Invisible Man. Ellison used the metaphor of invisibility not because he could not be seen but because people refused to see him. Hence he laments, "It is as though I have been surrounded by mirrors of hard, distorting glass" (p. 3). African American invisibility was further attested to by Jean-Paul Sartre, the most renowned twentieth-century existentialist. Based on what he saw after he had visited the United States in 1945, Sartre tells us, "In this country, deservedly proud of its democratic institutions, one man out of ten is deprived of his political rights; in this land of equality and liberty live 13 million untouchables" (1997, p. 84). "These untouchables," Sartre goes on to say, "you cross them in the streets at all hours of the day, but you do not return their stares ... if by chance their eyes meet yours, it seems to you that they do not see you and it is better for them and you that you pretend not to have noticed them" (p. 84). Sartre reminds us that these untouchables are not "all necessarily from the laboring class, yet the majority of them live in horrible misery; some are lawyers, doctors, professors, some manage major newspapers, ... but they count as (little) as the elevator boy in the eyes of whites" (p. 84). It is therefore no wonder that as a young Muslim minister, Malcolm X spoke out against the terrible treatment doled out to African Americans in the United States.

During the last ten years of his short life, Malcolm fought for social, political, and economic justice for African Americans and for black people throughout the world, for as he told Columbia University students, "It is incorrect to classify the revolt of the Negro as simply a racial conflict of Black against white, or as a purely American problem. Rather ... we are today seeing a global rebellion of the oppressed against the oppressor, the exploited against the exploiter" (1992b, p. 177). He maintained forcefully that "the oppression of Blacks in the United States cannot be separated from the oppression of Africans on the African continent and in the world. ... What happens to a black man in America today happens to the black man in Africa. What happens to a black man in America and Africa happens to the black man in Asia and to the man down in Latin America" (qtd. in Stull, 1999, p. 88). Jennings (2002) argues, "In living and speaking from the intelligence of his heart, Malcolm X spent a dedicated life to formulating a reconfiguration of his people" (p. 140). Malcolm was indeed the greatest critic of the subjugation and dehumanization of black people in America. Like Aime Cesaire before him, Malcolm spoke of millions of black people "who have been skillfully injected with fear, inferiority 
complexes, trepidation, servility, despair (and) abasement" (qtd. in Fanon, 1967, p. 7). West (1994), argues that "Malcolm X sharply crystallized the relation of black affirmation of self, black desire for freedom, black rage against American society, and the likelihood of early black death" (p. 137). Malcolm spent most of his adult life deliberating and addressing the concerns of African American existence (being) in the United States in light of his personal experiences. He sought to bring to the fore African American problems regarding their existence in America and was particular about such existence in its philosophical, cultural, and historical contexts. Malcolm addressed himself to African American concerns as he himself was involved in them. Cone (1991) contends that Malcolm X expressed "what it felt like to be black in white America" and "spoke from the authority of his own experience" (p. 16). That is, he spoke of a society where being black meant misery, degradation, and suffering. In addressing African American existence or being, Malcolm appealed to logic and reason and used the platform of the Nation of Islam and the Islamic religion. Through the use of the language of the common man, compelling logic, and Islamic folk narratives, Malcolm criticized domination in America and searched for truth in history and social reality. He was particularly concerned with the lack of critical attention given to the established way of viewing reality, especially as it relates to race relations in America. He argued that not only do the "established powers keep vital knowledge and truth in their own circles, but they also produce an alternative form of truth, something else that they invent and put out for the masses" (qtd. in Karenga, 1993, p. 10). Malcolm called for the psychological return of African Americans to Africa through the study of history aimed at reforming and transforming African American thought as was suggested by Carter G. Woodson. Malcolm pointed out that "just as a tree without roots is dead, a people without history or cultural roots also become a dead people" (1970, p. 16). Malcolm was also concerned about the social constraints imposed on African American freedoms, particularly with respect to self-determination and liberation of the human mind. He decried the "concept of superior culture and power which were used as instruments of domination and oppression." Malcolm's critique ushered in major debates which formed the foundation for developing "intellectual assault on domination" as well as the foundation for the liberation of African American consciousness. Out of Malcolm's analysis emerged a new theoretical language that Karenga (1993) calls "emancipatory reasoning" (p. 7). Karenga defines emancipatory reasoning as "reasoning dedicated to undermining and overthrowing constraints on human thought and freedom." As he puts it, the purpose of emancipatory reasoning is to "promote conscious 'transformative' activity" (p. 7).

During his last ten years, Malcolm explored the wider terrains of U.S. social and intellectual history. He brought to light the structural inequality in American society and effectively challenged dominant assumptions. He called on America to live up to its promise of substantive democracy, critical citizenship, and social responsibility. He was bent on stopping those ideological and social practices in America that were at odds with the goals and ideals of democracy. ${ }^{1}$ His major con- 
cern was "to redeem self-esteem and integrate the divided consciousness of African Americans that four hundred years of racism and oppression had visited upon them" (Roda, 2005, p. iii). He made his points known by lecturing and debating "at universities, mosques, churches, and various other gatherings, in formal and informal gatherings, . . . charging his audience to examine carefully and to discover contradictions in both the ideology and practices of American democracy" (Karenga, 1993, p. 7). He invited guest speakers such as Dick Gregory, Abdul Rahman Muhammad Babu of Tanzania, and Mrs. Fannie Lou Hamer to address his audiences. Karenga (1993) argues that Malcolm's critical analysis revealed a society plagued by complex, urgent, and provocative problems. For Malcolm, then, the main objective was "to engage in critical dialog and discovery to attempt to understand and overcome these obstacles to truth, human freedom and vital human exchange" (p. 7). In all his engagements, however, Malcolm was committed to the pursuit of truth, freedom, justice, and equality. He believed that these were major concerns of human beings and it would not only be irrational but "unethical, even anti-human to reason or act in such a way to deny this" (p. 9).

Dialogue was for Malcolm a way of checking society's personal, egocentric, and sociocentric biases. Thus, he attempted to formulate a critical dialogue committed to empowering African Americans and transforming the larger social order in the interest of a more just and equitable democracy. The central issue was to "debate the dominant society." Malcolm dealt with questions regarding the relationships between power and knowledge, learning and empowerment, authority and human dignity. He argued that American schools were places that produced not only subjects but biases. Hence, he told students at Boston University that the Eurocentric "educational system ... [is] designed to make you think you are God; [that] there is no one like you and everyone else is below you" (qtd. in Karenga, 1993, p. 10). On the contrary, Malcolm thought that schools should be sites for educating critical citizens who would be capable of exercising power over their own lives. At stake was a reconstruction of a democratic idea of citizenship that dignifies and critically engages the different voices that make up the American mosaic. This meant affirming those histories, traditions, stories, and events that had been denied their legacies in the struggle for democracy and social justice. In short, Malcolm was engaged in a discourse that would extend the principles and practices of human dignity, liberty, and social justice to all. As West (1994) aptly points out, "Malcolm... called for the realization that black people are somebodies with which America has to reckon" (p. 57). Malcolm refused to allow others to define for him what it meant to be African American. In short, Malcolm made it clear to the entire world that African Americans exist in a true philosophical sense. Epps (1991) describes Malcolm's achievement as critically important because it dealt with "the 'inner emancipation' of the black people" (p. 1) by advocating the idea that "civic life meant to counter ideas of racial inferiority and encourage race pride and civic improvement" (p. 9). 
Malcolm championed a cause that inspired hope for the future and brought fundamental changes in American society, particularly in the way blacks viewed themselves and were viewed by others. He made African Americans unashamed of who they were and where they came from. For Malcolm, to exist was to participate ontologically and to share in every aspect of the history of the human race rather than to engage in mere incidental existence. Malcolm addressed the existential dimension of African American reality and gave African Americans back their spirit, their lost humanity, and their dignity. In other words, Malcolm dealt with "issues of personal identity and the meaning of life" (Epps, 1991, p. 3). Malcolm was also concerned about issues of fairness and distributive justice in America and even more so about respect and dignity for all.

\section{Summary}

As we have seen, Malcolm X went through a process of education, mis-education and re-education. Malcolm X's life story is the exemplification of and the best way to demonstrate to students John Dewey's principle of interaction and continuity. Using Dewey's theoretical construct of education as growth to conceptualize, I conclude that some of Malcolm X's early experiences were not educative, but Malcolm's re-education through the instrumentality of the Nation of Islam was educative because it started him on the path of self discovery, self analysis, and the moment of struggle.

\section{Note}

1. By democracy, I am referring to a practice informed by the principles of freedom, equality and social justice. In its most emancipatory form, it challenges all citizens to construct and share power within the expanding needs of rights and obligations.

\section{References}

Carver, R. L. \& Enfield, R. P. (2006). John Dewey's philosophy of education is alive and well. Education and Culture, 22(1), 55-67.

Cone, J. H. (1991). Martin \& Malcolm \& America: A dream or a nightmare. Maryknoll, NY: Orbis Books.

Dewey, J. (1966). Democracy and education. New York: The Free Press. (Original work published 1916).

Dewey, J. (1998). Experience and education. West Lafayette, Indiana: Kappa Delta Pi. (Original work published 1938).

Ellison, R. (1994). Invisible man. New York: The Modern Library. (Original work published 1947).

Epps, A. (1991). Preface. In A. Epps (Ed.), Malcolm X: Speeches at Harvard (pp. 1-14). New York: Paragon House.

Fanon, F. (1967). Black skin, white mask. New York: Grove Press. 
Giroux, H. A. (2006). Higher education under siege: Implications for public intellectuals. The NEA Higher Education Journal: Thought \& Action, 22 (Fall), 63-78.

Graham, P. A. (2005). Schooling America: How the public schools meet the nation's changing needs. New York: Oxford University Press.

Jennings, R. (2002). Cheikh Anta Diop, Malcolm X, and Haki Madhubuti: Claiming and containing continuity in black language and institutions. Journal of Black Studies, 33(2), 126-144.

Karenga, M. (1993). The oppositional logic of Malcolm X: Differentiation, engagement and resistance. The Western Journal of Black Studies, 17(1), 6-16.

Lee, S. (1992). Malcolm X, The film. Burbank, CA: Warner Bros.

Malcolm X. (1970). Malcolm X on Afro-American history. New York: Pathfinder Press.

Malcolm X. (1991). Speeches at Harvard. (A. Epps, Ed.). New York: Paragon House.

Malcolm X. (1992a). The autobiography of Malcolm X as told to Alex Haley. New York: Ballantine Books.

Malcolm X (1992b). The final speeches (S. Clark, Ed.). New York: Pathfinder.

Martusewicz, R. A. (2004). Editor's corner. Educational Studies, 35(1), 1-6.

Roda, A. (2005). Preface. In M. O. Bassey, Malcolm X and African American selfconsciousness (pp.i-v). Lewiston, NY: The Edwin Mellen Press.

Sartre, J. P. (1997). Return from the United States: What I learned about the black problem. T. D. Sharpley-Whiting (Trans.), In L. R. Gordon (Ed.), Existence in black: An anthology of black existential_philosophy (pp. 83-89). New York: Routledge.

Stull, B. T. (1999). Amid the fall, dreaming of Eden, Du Bois, King, Malcolm X, and emancipatory composition. Carbondale: Southern Illinois University Press.

Waghid, Y. (2005). Action as an educational virtue: Toward a different understanding of democratic citizenship education. Educational Theory, 55(3), 323-342.

West, C. (1994). Race matters. New York: Vintage Books.

Western Journal of Black Studies (1993). Philosophy and ideology of Malcolm X: Theories and perspectives, 17(1), 1-51.

Woodson, C. G. (1993). The mis-education of the Negro. Trenton, NJ: Africa World Press, Inc. (Original work published 1933).

Magnus O. Bassey is Associate Professor of Education at Queens College, CUNY. E-mail: Mombasa4@msn.com 